\title{
INSECTS INVADE AN URBAN POOL
}

\author{
by E. A. DRIVER*
}

Most of us are familiar with the Aramatic migrations of the Monarch Butterfly (Danaus plexippus) from British Columbia to southern Califorhia or the Desert Locust (Schistocerca regaria) which migrates for thousands of miles in the Middle East during the dry seasons. Closer to home, many poorly known aquatic as well as errestrial insects move from one habitat to another for a variety of reasons. These movements may be as hort as several hundred feet or as long is 50 miles. Unfortunately, few migrations are observed. Many insects are not noticed because they are drab or dark coloured or small and so we may fail to appreciate this henomenon.

Many aquatic insects can travel tgainst the wind while others are ransported on strong winds. Wind in luences the direction of travel but the duration of flight (migration) is conrolled by the insect.

Aphids, mosquitoes, butterflies and ther insects begin to migrate soon after they emerge from the nymph or pupa stage. Many will fly en masse from the emergence site to a new breeding area. Some fertilized female mayflies (Hexagenia bilinuta) migrate 12 miles from river to lake'. Aquatic insects are forced to migrate as ponds dry up.

There are several kinds of migration: migration away from the place of birth without return or migration to hibernation sites and return to similar breeding habitat (also see Johnson ${ }^{2}$ ). Aquatic insects par- ticipate in both types of migration.

Many dragon- and damsel-flies begin migration immediately after emergence from the water. Whiteface dragonflies (Leucorrhinia) and the large Blue Darners (Aeschna) pursue an outward migration after the teneral stage (the teneral stage of an insect is the period immediately after the insect moults or emerges) and do not return to their natal site.

Several species of butterflies and mosquitoes display the second type of migration, for example, the Monarch Butterfly and a mosquito (Anopheles earlei). This anopheline mosquito emerges from roadside ponds, flies several miles to overwinter in ground squirrel burrows and in spring finds a temporary pond to lay her eggs in.

The following is an example of local insect migration in Saskatoon.

Our neighbor's unused swimming pool is bordered by Cut Leaf Weeping Birch (Betula pendula gracilis), Manchurian Elm (Ulnus pumila) and a large bed of Hansa Roses (Rosa rugosa hybrid). Leaves from these trees and shrubs combined with dust in the pool provided an excellent habitat for lar val stages of aquatic insects. The litter varied from less than $6.3 \mathrm{~mm}$ (1/4 inch) to $31.7 \mathrm{~mm}$ (11/4 inches) in depth. Water in the pool was maintained at a maximum depth of $122 \mathrm{~cm}$ (4 feet).

In the fall of 1972 several species of predaceous diving beetles (Dytiscidae) were noted in the pool. In August, 1973, after the pool had stood undisturbed for 4 months, I observed a large number of midge (Chironomidae) pupa exuvia (the 

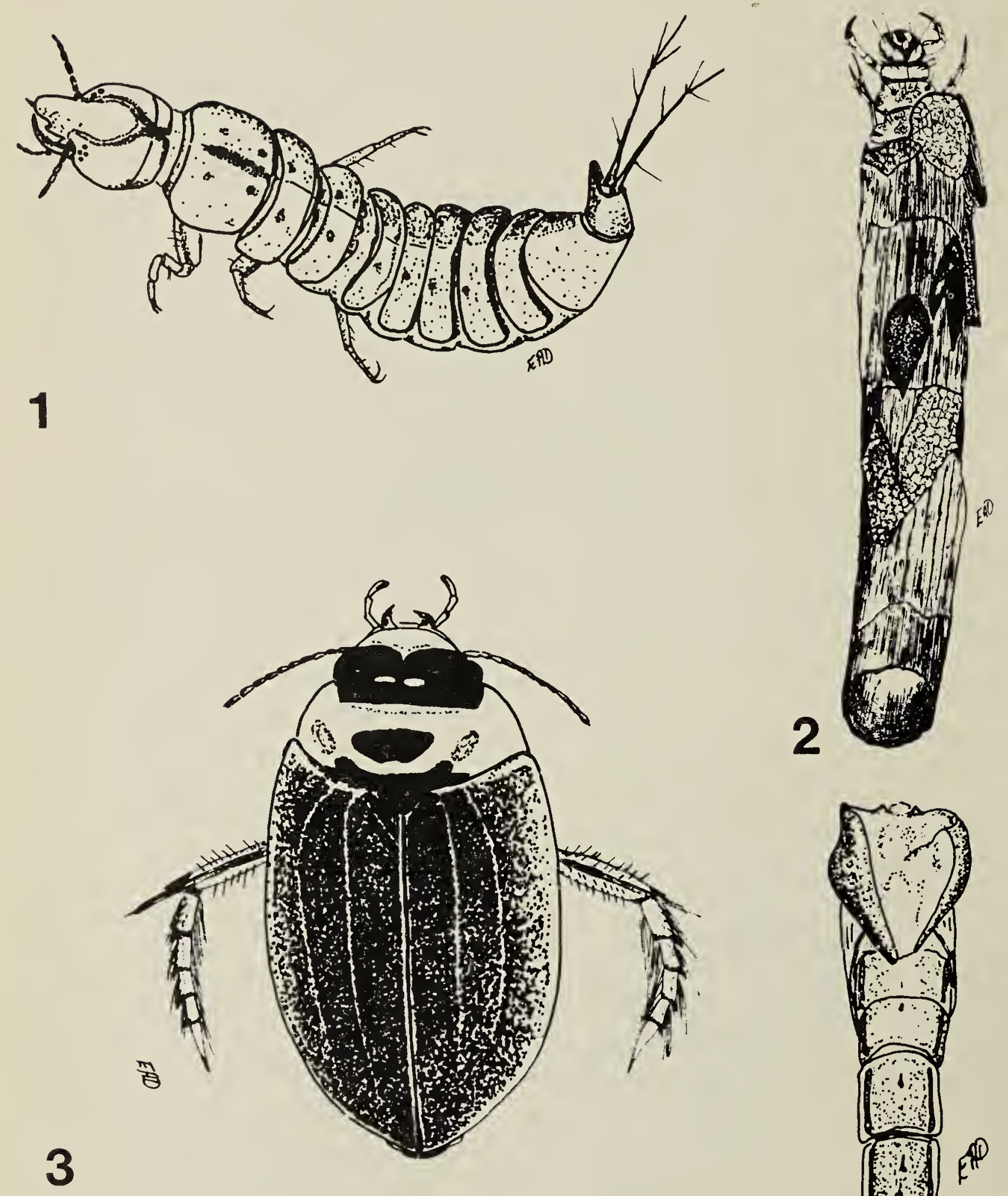

Figure 1. Predaceous diving beetle larva, Hydroporus sp., length $5 \mathrm{~mm}$

Figure 2. Caddisfly larva, Phryganea cinerea, case constructed from leaves and grass clippings, length $10 \mathrm{~mm}$

Figure 3. Predaceous diving beetle, Rhantus notatus, length $8 \mathrm{~mm}$

Figure 4. Pupa exuvia of the midge, Phytotendipes barbipes, length $6 \mathrm{~mm}$

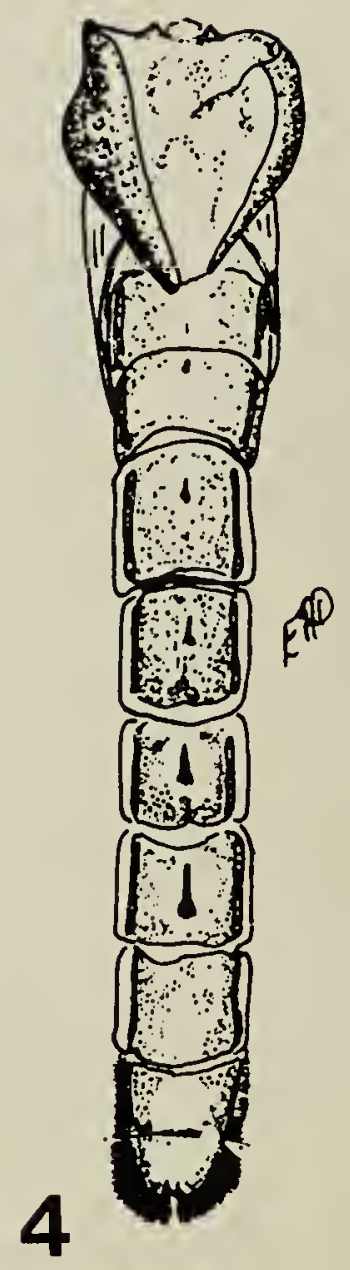


Table I. Insects collected from a swimming pool in Saskatoon, Saskatchewan.

Species

Dragon- and damsel-flies (Odonata) Aeschna i. interrupta

Lestes disjunctus

Water striders (Hemiptera)

Gerris dissortis

Gerris buenoi

Backswimmer (Hemiptera)

Notonecta undulata

Water Boatmen (Hemiptera)

Corisella taralis

Trichocorixa sp.

Callicorixa audeni

Water scavenger beetles (Coleoptera)

Tropisternius lateralis numbatus

Whirligig beetles (Coleoptera)

Gyrinus maculiventris

Predaceous diving beetles (Coleoptera)

Rhantus notatus

Agabus bifarius

Hydroporus sp.

Helophorus oblongus

Helophorus sp.

Hygrotus patruelis

Hydrovatus sp.

Caddisflies (Trichoptera)

Phryganea cinerea

Mayflies (Ephemeroptera)

Callibaetis group

\section{Ephemerella}

Midges (Diptera: Chironomidae)

Phytotendipes barbipes

Tanytarsus sp.

Psectrotanypus guttularis

Psectrocladius barbimanus
Life stages

Adult female drowned

Adult female attempting to

deposit eggs on side of pool

Adult male standing on water

Adult female and nymphs skating on water

Adult male swimming

Adult female feeding on algae on side of pool

Adult female swimming

Adult female and nymphs swimming

Adult male swimming

Adult swimming on water surface

Adult female swimming

Adult female swimming

Nymph swimming

Adult swimming

Adult swimming

Adult swimming

Adult swimming

Larva crawling on litter at bottom of pool

Adult female and nymph exuvia at water surface, nymphs swimming Adult female on water

Pupa exuvia floating on water, larva crawling in litter at bottom of pool Adult female and pupa exuvia on water Larva feeding in litter and pupa exuvia floating on water Adult male partially emerged from pupa exuvia at water surface 
Acricotopus nitidellus

Cricoptus sp.

Corynoneura sp.

Phantom midge (Diptera; Chaoboridae)

Chaohorus americanus

Bees (Hymenoptera)

Bombus sp.

(bumble bee)

Apis mellifera

(honey bee)

Iphids (Homoptera)

Rhopalosiphum naidis

(Corn Leaf Aphid)

Macrosiphum dirhodum

(Rose Grass Aphid)

Macrosiphum avenae

(English Grain Aphid)
Adult male and pupa exuvia at water surface

Adult male and female and pupa exuvia

Larva living in litter at bottom of pool

Larvae swimming

Adult drowned

Adult wet on water surface

Adult males sitting on water

Adult males sitting on water

Adult males sitting on water
Two interesting facts were gleaned from the swimming pool. First, a moderately barren habitat, lacking rooted aquatic plants, was able to support a diverse aquatic insect community and, secondly, this community was more complex than those I have studied in some natural wetlands. Ponds that hold water for 4 to 15 weeks near Floral, Saskatchewan, had an average of 10 species of aquatic insects with a range of 5 to 24 species per pond. The total for 10 temporary ponds was 28 species. (These totals may be low because species could have been missed during sampling.) More permanent ponds in the same area support aquatic insect communities in excess of 70 species.

\section{A HOME PROJECT}

Anyone can place a tub or pail filled with water in the backyard, visit the "pool" weekly and record the number and kinds of insects. A dugout or pond serves the same purpose. Collecting and preserving one or more of each kind of insect you find may be the best way to keep track of how many kinds appear in your "pool". A seive or dip net is as good as anything for collecting. Preserving insects is more complicated. You may wish to use one vial for each kind of insect or put them all in one or more larger bottles. Rubbing alcohol or formaldehyde, available from either a drugstore or hardware, will keep your collection in life-like condition for years.

To check the direction of migration, an old storm window can be set up on each side of a dugout. A small tray filled with a soap solution at the base of each side of a window will catch insects which strike it and give an indication of what direction they are moving.

To identify many of the insects, " $A$ field guide to the insects" by D. J. Borror and R. E. White (1970), part of the Peterson Field Guide Series, is very useful. Other books can be obtained through a local library.

I wish to thank Ulrich Hochwald for 
photographing the insects and Maurice Taylor, Canada Department of Agriculture, Saskatoon, for identifying the aphids.

1BURKS. B. D. 1953. The mavflies or Ephemeroptera of Illinois. Natural History Survey, Urbana, Illinois. $216 \mathrm{pp}$.

2JOHNSON, C. G. 1969. Migration and dispersal of insects by flight. Methuen and Company, Ltd., London. $763 \mathrm{pp}$.

Students wishing a eopy of this paper may obtain it by writing the author.

\section{A WHITE-BANDED DAY SPHINX MOTH - NEW TO MANITOBA}

by WALTER V. KRIVDA*
In sorting and arranging a twenty five year collection of Sphinx moths it the writer's collection at The Pas various new records for the provinc are being discovered.

The present, apparently unique specimen for Manitoba was collected in the southeastern part of th province at Brokenhead, Manitoba June 6, 1954, Dan Mosquin, collector It is somewhat worn showing distan migration. The specimen is somewha on the small side and likely is of th first generation.

The White-banded Day Sphin, Moth is common in southern Florid and native throughout South America Previous migrant records are known a far north as Massachusetts, New York Michigan and Missouri, but this is th first record for Manitoba.

* Keewatin Community College, P.O. Box 300,

The Pas, Manitoba.

R9A $1 \mathrm{M} 7$

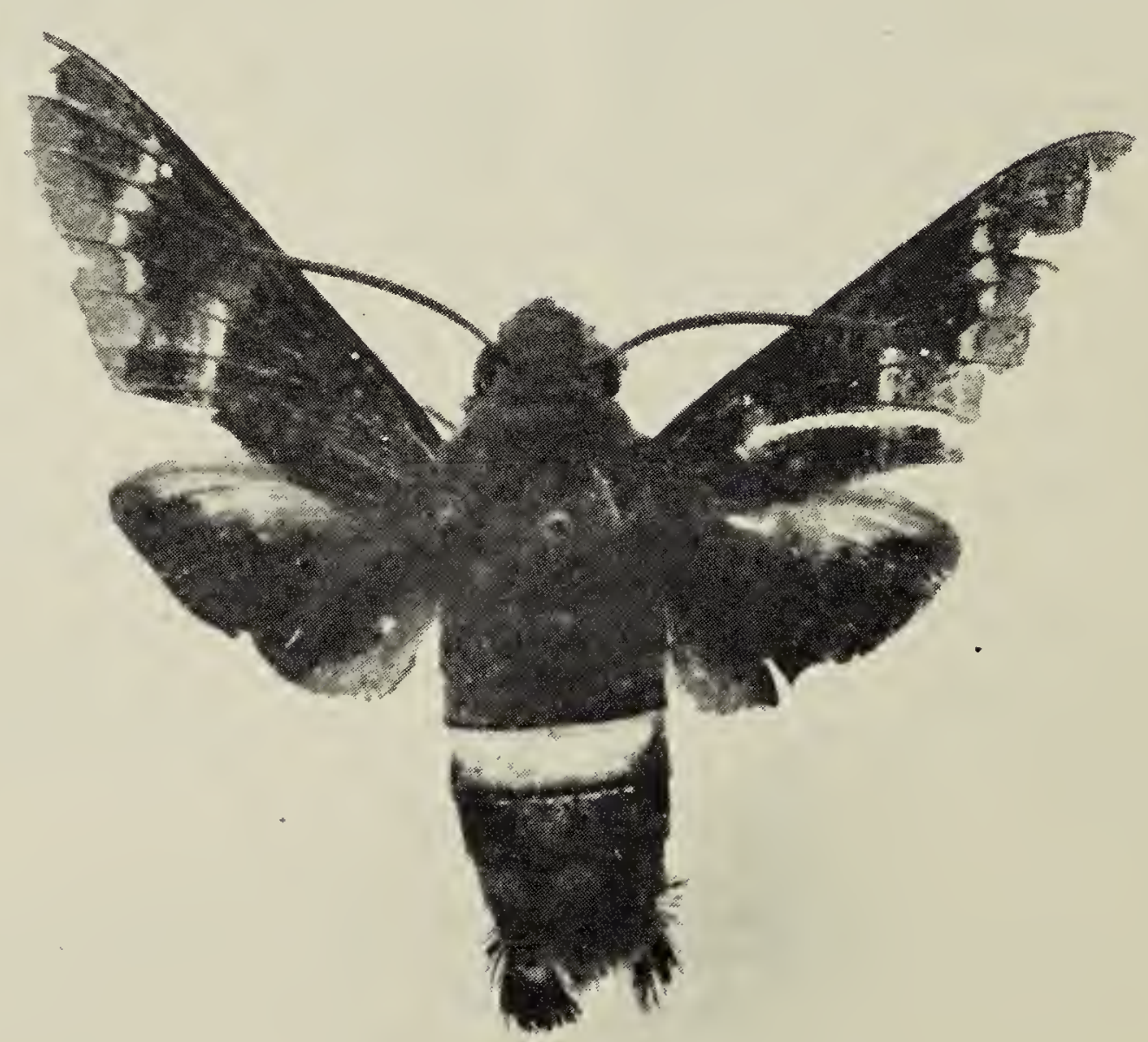

